\title{
The Effectiveness of Multimedia Language Courseware on Secondary School Students' Motivation for learning English
}

\author{
Shayes hteh Hashemyolia \\ Faculty of Educational Studies, Universiti Putra Malaysia \\ Email: shayesteh hashemi@yahoo.com \\ Ahmad Fauzi Mohd Ayub \\ Faculty of Educational Studies, Universiti Putra Malaysia \\ Institute for Mathematical Research, Universiti Putra Malaysia \\ Zahra Moharrer \\ Faculty of Modern Language and communication Universiti Putra
}

\begin{abstract}
Integration of multimedia language courseware (MLC) has been wildly practiced in teaching and learning of English as a Foreign Language (EFL). The purpose of this study was to determine the effects of MLC on secondary students' motivation in its five dimensions of intrinsic, extrinsic, self-efficacy, relevance, and anxiety in a public school in Iran. This study utilized a quasi-experimental method using only the post-test design which consists of 62 participants in two groups. The control group was taught in only the traditional method and the experimental group was also taught in a face-to-face environment while using MLC. In addition, the inferential statistical analyses revealed that there was significant difference between the groups on the overall motivation in support of the experimental group. Accordingly, MLC can motivate learners to engage in learning process and they are interested in and satisfied with utilizing MLC in class room.
\end{abstract}

\section{Keywords}

Multimedia English language courseware, students' motivation in learning, intrinsic, extrinsic, self-efficacy, relevance, and anxiety dimensions.

\section{Council for Innovative Research}

Peer Review Research Publishing System

Journal: Journal of Social Sciences Research

Vol. 9, No. 2

jssreditor.cir@gmail.com

www.jssronline.com 


\section{INTRODUCTION}

Computer has become a significant factor in second language learning which can create both independent and collaborative learning settings (Zacharis, 2010). Integration technology in language skills, such as listening, speaking, reading and writing can make teaching and leaming processes more interesting for students (Graff, 2006; Almekhlafi, 2006; Wu, Tennyson, \& Hsia, 2010). Language cours eware not only is able to facilitate leaming but also can create a higher level of motivation among students by doing at their own pace (Greany, 2007). Ministry of Education (MOE) in Iran plans to develop information communication technology (ICT) applications in schools in order to change the teaching and leaming practices (Kousha, 2004).

Motivation is the internal stage of the student's behavior towards achieving a certain goal (Bandura, 2005). Students who seek for information, effort to understand, and reach the mastery perfomance are more intrinsically motivated. Extrinsically motivated students perform activities in order to obtain some rewards such as good grades, or teacher's approval or avoid some punishments (Glynn, Taasoobshirazi, \& Brickman, 2009). Language courseware would raise student's motivation by providing more opportunities for students to interact with authentic contexts.

The use of several media, audio, video, authentic contexts and real world experiences help language learners possessing different learning styles to ass imilate the content according to their needs (Kumar \& Tammelin, 2008). Multimedia provides different learning facilities for students to do further practices on various language skills in order to accommodate individuals' needs and interests. This situation makes leaming environment more interactive, dynamic, enjoyable, and interesting (Kalnina \& Kangro, 2007).

Lack of motivation leads the students to high anxiety (Glynn, et al., 2009). Multimedia courseware can reduce the student's anxiety and increase their motivation during language learning. They feel relaxed and dynamic learning because they learn in their own space without a fear of classmates or the teacher's feedback (Andrade \& Williams, 2009). Multimedia technology diminishes learning stresses and anxieties by supplying students with a huge number of fun games and communicative activities. According to study of Andrade and Williams (2009), practicing without any distress of failing is one of the means of language courseware that allows individuals to find the goal by employing trial and error without any anxiety. Moreover, it encourages students towards the goal of developing their understanding and competence (Andrade \& Williams, 2009). A student can choose a favorable learning path, materials, and time for learning at his/her convenience. The testing and evaluating module provided by an instructional designer of the language courseware for learners is a key important factor to crate motivation towards language learning (Andrade \& Williams, 2009).

The computer provides opportunities for students to be less dependent on the teacher and have more freedom to do experiments on their own in a language setting (Al-Mansour \& Al-Shorman, 2011). Consequently, such a challenging situation leads the students' motivation towards further learning, gaining more confidence, a higher achievement, and more complex challenges. In this case, the instructor should provide a complex learning environment that motivates students to challenge and motivation.

This study is based on the social cognitive leaming theory and constructivist theory the outcomes of which are critical thinking, understanding, use of knowledge, and self-regulation. In the social-cognitive theory of human learning (Bandura, 2005), students' characteristics, behaviors, and learning environments have an influence on each other. According to this theory, learning is most effective when self-regulated leamers understand, monitor, and control their own cognition, motivation, and behavior (Schunk, Pintrich, \& Meece, 2008). Motivated learners engage in behaviors such as question asking, advice seeking, studying, and participating in study groups in order to achieve learning (Schunk, et al, 2008).

Constructivism integration with education emphasizes that learners should be engaged actively with the learning process. In addition, the constructivist theory leads the students' motivation to further learning and higher achievement (Vygotsky, 1978). Therefore, a pedagogical design should support and satisfy individual learners' requirements and interests (Bernacki, Aguilar, \& Byrnes, 2011). The instructional approach of constructivism highlights student-centrism rather than teacher-centrism as the mere source of knowledge in the classroom. Computers provide pervasive opportunities for students to be less dependent on the teacher and have more freedom to experiment on their own in a language setting; thus, such an environment encourages and motivates students to learn a language (Chen \& Wu, 2012).

Based on a survey study conducted by Zhang (2007) on 14 American students who studied in an elementary Chinese course via computers in classroom in Eau Claire College, the researcher found that computers provided many benefits in the language course. It allowed the students to learn more language knowledge and skills in a shorter period of time than a regular course. On the other hand, students had higher motivation in the classroom. Technology could significantly enhance student's capability in problem solving and in learning by doing. Computers increased students' opportunities for self-directed leaming.

In another study carried out by Vernadakis and colleague (2008), they found that multimedia could help language learners' motivation, support their language skills, affect their leaming attitude, and build their self-confidence through various communicative and interactive activities. Their findings indicated that the multimedia language courseware, by providing the test items, allows every individual to assess their own learning components confidently (Vernadakis, Zetou, Tsitskari, Giannousi, \& Kioum ourtzoglou, 2008). 


\section{OBJECTIVES}

The purpose of this study was to compare the effectiveness of utilization the multimedia language courseware (MLC) compared to the traditional method on the students' motivation in leaming English. The students' motivation was measured on the basis of the individual and overall motivation dimensions of intrinsic, extrinsic, self-efficacy, relevance, and anxiety.

\section{HYPOTHESIS}

$\mathrm{H} 01$ : There is no significant difference of intrinsic motivation among the students who used MLC compared to the traditional method?

H02: There is no significant difference of extrinsic motivation among the students who used MLC compared to traditional method?

H03: There is no significant difference of self-efficacy among the students who used MLC compared to traditional method?

H04: There is no significant difference of personal relevance among the students who used MLC compared to the traditional method?

$\mathrm{H} 05$ : There is no significant difference of anxiety among the students who used MLC compared to the traditional method?

H06: There is no significant difference of motivation in the overall dimensions among the students who used MLC compared to the traditional method?

\section{METODOLOGY}

This study applied the post-test quasi-experimental control group design. This study is designed to compare the effectiveness of using the MLC on the student's motivation. The sample of the study was taken from the secondary school students. The sample was drawn 31 students in the experimental group and control group. The control group was sitting in traditional classroom who leam from text book and blackboard only. The experimental group also was settled in traditional classroom but use MLC as supplementary tools that may enhance teaching and learning. The mean of the participants' age was 14 years old.

After four weeks intervention using the MLC and traditional method, a questionnaire was given to both groups to determine how much MLC influenced students' motivation by the five-point likert scale questionnaire $(1=$ never, $2=s e l d o m$, $3=$ sometimes, $4=$ usually, and 5=always). The questionnaire by Glynn et al. (2008) was modified. It consisted of 24 items in five dimensions (i.e., intrinsic, extrinsic, self-efficacy, personal relevance, and anxiety). The reliability and validity of questionnaire was confirmed by pilot study among 25 individuals with the same characteristics of the sample.

The data were analyzed using Statistic Package of Social Science (SPSS) version 16. Descriptive statistics and an independent sample $t$-test were applied in this study. Also Eta-squared ( $\eta 2)$ used to measure the effect size for $t$-test that ranges for the critical value is between $0-1 \quad(0.01=$ small, $0.06=$ medium, and $0.14=$ large). SPSS cannot measure Etasquared ( $\eta 2$ ); therefore, the researchers calculated it manually by using Cohen's (2007) formula:

$$
\not^{2}=\frac{t^{2}}{t^{2}+d f}
$$

The value of formula obtained from t-table of $t$-test calculation.

\section{Rosetta Stone English Language Courseware}

This study used Rosetta Stone English Language Courseware RSELC as the multimedia program software. RSELC facilitates teaching and learning process by utilizing various interactive technologies. During learning activities through RSELC a leamer engages and leams more effectively while enjoying learning. RSELC creates an individual learning space that learners are able to leam on their own pace; therefore, they learn materials confidently. Such an interactive learning environment by integrating various applications of audios, texts, and pictures encourage learners to persist and make attempt to accomplish a task (Figure 1).

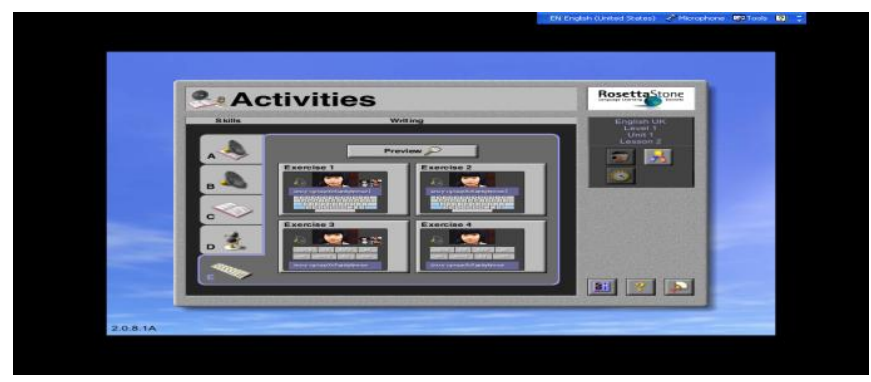

Figure1. The Main Menu of RSELC 


\section{FINDINGS}

The discussion on the findings was based on the six hypotheses proposed earlier. The statistical analys is used in the study was the independent sample $t$-test to examine the students' motivation scores based on the two different types of instructional formats. The results are shown in Table 1.

Table 1: Independent sample $t$-test re sults of students' motivation between two groups

\begin{tabular}{|c|c|c|c|c|c|c|c|c|}
\hline Hypotheses & Groups & $\mathbf{N}$ & Mean & SD & & $T$ & df & Sig \\
\hline$\overline{\mathrm{H}_{01}}:$ & CG & 31 & 3.64 & 0.86 & 0.774 & & & \\
\hline \multirow[t]{2}{*}{ Intrinsic } & & & & & & 3.55 & 60 & 0.000 \\
\hline & $E G$ & 31 & 4.31 & 0.48 & 0.439 & & & \\
\hline $\mathrm{H}_{02}:$ & $\overline{\mathrm{CG}}$ & 31 & 2.54 & 0.61 & 0.554 & & & \\
\hline \multirow[t]{2}{*}{ Extrinsic } & & & & & & 6.93 & 60 & 0.000 \\
\hline & $E G$ & 31 & 3.45 & 0.39 & 0.350 & & & \\
\hline $\mathrm{H}_{03}:$ & $\overline{\mathrm{CG}}$ & 31 & 3.54 & 0.98 & 0.884 & & & \\
\hline Self-efficacy & & & & & & 2.91 & 60 & 0.005 \\
\hline & $E G$ & 31 & 4.13 & 0.53 & 0.478 & & & \\
\hline & $\overline{C G}$ & 31 & 3.14 & 0.70 & 0.632 & & & \\
\hline $\mathrm{H}_{04}:$ & & & & & & 7.26 & 60 & 0.000 \\
\hline Relevance & $E G$ & 31 & 4.26 & 0.49 & 0.443 & & & \\
\hline $\mathrm{H}_{05}$ : & $\overline{C G}$ & 31 & 3.32 & 0.71 & 0.643 & & & \\
\hline \multirow[t]{3}{*}{ Anxiety } & & & & & & 5.044 & 60 & 0.000 \\
\hline & $E G$ & 31 & 2.50 & 0.57 & 0.516 & & & \\
\hline & $\overline{C G}$ & 31 & 2.67 & 0.70 & 2.09 & & & \\
\hline $\mathrm{H}_{06}:$ & & & & & & 5.54 & 60 & 0.000 \\
\hline Overall & $E G$ & 31 & 3.35 & 0.45 & 1.20 & & & \\
\hline
\end{tabular}

The intrinsic motivation of students refers to the students' effort to gain the goals. Also students like to continue with the lesson in the same way. In this study, five items were used to measure students' intrinsic motivation in learning English. Table 1 displays the mean and standard deviation of intrinsic motivation items which have higher value in the experimental group. The results indicate that the students who used Rosetta Stone language were engaged in more grammar tasks. They found it more interesting and enjoyed teaching and learning process es. The result of the $t$-test shows that there is significant difference of intrinsic motivation among those students who used language courseware $(M=4.31, S D=0.48)$ compared to their counterparts in the traditional model $(M=3.64, S D=0.86 ; t=3.55 p=0.001<0.05)$ and Eta-squared $=$ 0.17 shows the difference between mean scores is large. The findings confimed that students who used the language course had more motivation to challenge with the grammar in order to achieve deep learning. The experimental group had higher intrinsic motivation in learning English grammar compared to the control group.

The extrinsic dimension refers to the student's motivation by outside factors than those of their self. They participate in activities to receive rewards or avoid punishments. For instance, they learn English grammar to get a good grade or job in future. The data from descriptive analysis illustrates that students in the experimental group reach a higher mean score in all four items of extrinsic motivation compares to the control group. Consulting an independent sample $t$-test shows that there was a significance difference in the students' extrinsic motivation for the control group $(M=2.54, S D=0.61)$ compared to the experimental group $(M=3.45, S D=0.39 ; t=6.93, p=0.000)$. Eta-squared $=0.44$ indicates that the magnitude of mean scores is large (Cohen, et al., 2007). These findings confimed that the students in the experimental group had a higher extrinsic motivation in learning English grammar compared to the control group.

The third dimension of students' motivation conducted in the students' self-efficacy in learning English course. It refers to the students' beliefs or confidence to do master in knowledge and skills of English grammar. Based on the data obtained from the means and standard deviation in five items show that the experimental group had higher confident in learning English grammar than the control group. The independent $t$-test value shows that there is a significance difference at students' self-efficacy in leaming English grammar between two groups. The control group had $(M=3.54, S D=0.98)$ compared to the experimental group $(M=4.13, S D=0.53, t=2.91, p=0.005)$ and Eta-squared $=0.12$ reveals a moderate difference. Consequently, the students in the experimental group had a higher level of self-confidence to 
perform better than the other group. RSELC enabled students to practice repeatedly until they made sure that they learned the content.

In this study, the student's opinion about the relevance of learning English and their personal goals was investigated. It was organized in five items which referred to how much students used the English course and it was helpful to them. The mean and standard deviation are presented in Table 1. It demonstrates that all items that used to measure students' relevance in grammar have higher mean scores for students who used the language courseware. Furthermore, according to the results of the independent $t$-test, there was a significant difference in the relevance of the English grammar course of the students' perceptions for the experimental group $(M=4.26, S D=0.49)$ and the control group $(M=3.14, S D=0.70$, $t=7.26, p=0.000<0.05)$. According to Cohen et al., (2007), Eta-squared $=0.46$ reveals that the size of difference in the mean scores was large. This finding showed that the students in the control group believed that what they learned of English did not have practical values while the experimental group who believed that the lessons would be more helpful to them and they could use the materials in their real life situations.

The students' anxiety to the English course referred to the last dimension of motivation in this study. It refers to students' fear and anxiety in failing the English exam. Table 1 illustrates that the five-item mean score and standard deviation of anxiety in the traditional method and courseware method. As a reverse scored items, the data analysis shows that the students' anxiety in the control group was higher than the experimental group. The independent $t$-test confims that there is significant difference in the students' anxiety of the control group $(M=3.32, S D=0.71)$ and the experimental group $(M=$ $2.50, S D=0.57, t=5.04, p=0.000<0.05$ ) moreover, the effect size $=0.29$ indicates that the size of difference in the mean score was large. This finding shows that, language courseware significant decreased the student's anxiety to English grammar course compare to traditional method.

The results of independent sample $t$-test in Table 1, as an overall composition in the dimensions of motivation calculated from each group, display that there is significant difference in the rate of motivation between the two groups. The control group $(M=2.67, S D=0.70)$ and the experimental group $(M=3.35, S D=0.45, t=5.54, p=0.000<0.05)$ indicated that the students who used the courseware had higher motivation in learning. Eta-squared $=0.33$ show that there was a large difference. Therefore, RSELC had a large effect on the students' motivation in the particular dimensions such as intrinsic, extrinsic, self-efficacy, relevance and anxiety in learning English in the present study.

\section{DISCUSSION}

The purpose of this study was to investigate the effect of the language courseware on the students' motivation in the secondary level of education. The results of descriptive analyses indicated that mean scores of the students' motivation in the courseware method was higher than their counterparts in the traditional group. Also the independent sample $t$-test findings showed that there were significant differences between the experimental and control groups' motivation in the English grammar course.

The implications theoretical point of this study supports Social Cognitive Theory that provided a constructive framework for understanding and predicting students' motivation to leam in face-to- face classroom enhanced by multimedia language cours eware (Clearly \& Zimmeman, 2012). Theoretically, the advantage of such a leaming environment plays an important role in students' motivation to learn with different concepts (e.g., intrinsic, extrinsic, self-efficacy, relevance, and anxiety). It further offers authority and self-regulation leaming (Dabbagh, \& Kitsantas, 2012). The findings showed students' responsibility for their English leaming course. As matter of fact, the students evaluated themselves and their tasks, facilitated by multimedia language courseware, to achieve the leaming goals.

The result of intrinsic motivation supported another finding which stated that intrinsically motivated students had tendency to employ more efforts which enabled them to obtain deep understanding (Bandura, 2005). In the experimental group, the students were able to control their progress because they could practice repeatedly as often as necessary. Such a control increased students' motivation to administer more challenges with a task. The students who used the language courseware believed that they would be master in the English course. This result confims the previous research which reported the computer-based learning increased the students' self-confidence (Greany, 2007).

The multimedia language courseware prepared the lesson in daily activities which could attract the students' motivation to learn more because they believed that what they learned related to their life situations. In reliance with other studies, computers integrate pictures, sounds, animations, and tasks to create an environment that students can use grammar in real activities simulated to world around them (Greany, 2007; Zhang, 2007; Graff, 2006).

Generally, computer-based learning prepares the students' opportunities to leam by their own pace by trial and error without any pressure (Andrade \& Williams, 2009; Kalnina \& Kangro, 2007). The findings reviled that students in the experimental group did not have any fear during practices. They felt relaxed and enjoyed teaching and leaming English grammar (Kumar \& Tammelin, 2008; Vernadakis, 2008).

\section{CONCLUSION}

This study aimed to explore the effects of applying the courseware on the students' motivation to learn English grammar in Grade 8 of a secondary school in Iran. The results of the study were analyzed based on the objectives of this study, which obtained from 62 individuals, showed that the majority of the students in the experimental group had a high positive perception towards using the courseware. The students enjoyed the time of teaching and learning and prefer to continue 
this method. The multimedia software was prepared for English learners to engage in an interactive environment where they found out the correct answers confidently.

\section{RECOMMENDATION}

Although the research results obtained were consistent with the idea that the courseware implication enhances the students' motivation to learn English course, much more systematic study need to identify how the language courseware interacts with other variables of students' attitude. Due to the limitation of this study, it desires more time and a larger number of individuals in different educational systems to investigate the potential weaknesses and strengths of using the courseware in learning English. There is a need to explore other levels of education including the primary, secondary and high school.

\section{References}

1. Almekhlafi, A.G. (2006). The effect of Computer Assisted Language Leaming (CALL) on United Arab Emirates English as a foreign language (EFL) school students' achievement and attitude. Journal of Interactive Learning Research, 17(2), 121-142.

2. Al-Mansour, N.S., Al-Shorman, R.A (2011). The effect of computer-assisted instruction on Saudi University students' learning of English. Journal of King Saud University - Languages and Translation.

3. Andrade, M., \& Williams, K, (2009). Foreign language leaming anxiety in Japanese. EFL university classes: Physical, emotional, expressive, and verbal reactions. Asia Pacific Education Review, 29, 1-24.

4. Bandura, A. (2005). The primacy of self-Regulation in health promotion. Applied Psychology an International Review, 54(2), 245-254.

5. Bekele, T. A. (2010). Motivation and satisfaction in intemet-supported learning environments: A Review. Educational Technology \& Society, 13 (2), 116-127.

6. Bernacki, M. L., Aguilar, A. C., \& Byrnes, J. P. (2011). Self-regulated learning and technology enhanced learning environments: An opportunity-propensity analysis. In G. Dettori and D. Persico (eds) Fostering self-regulated learning through ICT, 1-26. United States: Information Science Reference.

7. Chen, C. H., \& Wu. I. C. (2012). The interplay between cognitive and motivational variables in a supportive online learning system for secondary physical education. Computer and education, 58 (1), 542-550.

8. Cleary, T., \& Zimmerman, B. J. (2012). A cyclical self-regulatory account of student engagement: theoretical foundations and applications. Handbook of Research on Student Engagement. New York,USA.

9. Cohen, L., Manion, L., \& Morison, K. (2007). Research methods in education $\left(6^{\text {th }}\right.$ Ed). New York: Taylor and Francis Library.

10. Dabbagh, N., \& Kitsantas, A. (2012). Personal Leaming Environments, social media, and self-regulated learning: A natural formula for connecting formal and informal leaming. Intemet and Higher Education, 15, 3-8.

11. Glynn, S. M., Taasoobshirazi, G., \& Brickman, P. (2009). The Science Motivation Questionnaire: Construct validation with non-science majors. Joumal of research in science teaching, 46(2), 127-146.

12. Graff, M. M. (2006). A study of Rosetta Stone's effectiveness on improving English pronunciation. Online thesis of Master of Arts. California State University Dominguez Hills, CA.

13. Greany, S. J. (2007). Students perceptions on language learning in a technological environment: Implications for the new millennium. Language Learning and Technology, 20(7), 12-15.

14. Kalnina. S., \& Kangro. I. (2007). ICT in foreign language teaching and leaming at university of Latvia the light of the first project. ICT in Education: Reflections and Perspective, 14-16.

15. Kousha, K. (2004). Iran's national ICT education plan: An overview of the possibilities, problems and the programs. World Library and Information Congress.

16. Kumar, S., \& Tammelin, M. (2008). Integrating ICT into language teaching: Guide for institutions. Johannes Kepler University Linz.

17. Schunk, D. H., Pintrich, P. R., \& Meece, J. L. (2008). Motivation in education ( $3^{\text {rd }}$ Ed.). Upper Saddle River, NJ: Pearson.

18. Vernadakis, N., Zetou, E., Tsitskari, E., Giannousi, M., \& Kioumourtzoglou, E. (2008). Student attitude and learning outcomes of multimedia computer-assisted versus traditional instruction in basketball. Education and Information Technologies, 13(3), 167-183.

19. Vygotsky, L. S. (1978). Mind and society: The development of higher mental processes. Cambridge, MA: Harvard University Press. Retrieved from

20. www.elearningquides.net/guides/4b-GUIDES-TUTORS-EN.pdf

21. Zhang, H. Y. (2007). Computer-assisted elementary Chinese learning for American students. US-China Educational Review, 4(5).

22. Wang, Q. (2001). A generic model for guiding the integration of ICT into teaching and leaming. Journal of Innovation in Education and Teaching International, Special Issue, 45(4), 411-419.

23. Wu, J. H., Tennyson, R. D., \& Hsia, T. (2010). A study of student satisfaction in a blended e-leaming system environment. Computers \& Education, 55 (2010), 155-164. 